\title{
TRIBUTAÇÃO DIGITAL: ANÁLISE SOBRE A INCIDÊNCIA DE ICMS E ISSQN NA TECNOLOGIA STREAMING ${ }^{\star}$
}

\author{
Eduardo David Inda** \\ André Pedreira Ibañez ${ }^{* * *}$
}

\section{RESUMO}

O Streaming assumiu um grande espaço na economia e também na vida social dos brasileiros a partir da segunda década do século XXI, consistindo em uma das novas formas de consumo de material digital. À vista desse fenômeno, este artigo visa investigar a natureza da nova tecnologia, a fim de verificar a possibilidade de sua incidência no Imposto Sobre Circulação de Mercadoria e Serviço (ICMS) e/ou no Imposto Sobre Serviços de Qualquer Natureza (ISSQN). Aponta o entendimento que dispõe a doutrina sobre os impostos mencionados, a fim de verificar se as hipóteses de incidência de ambos se aplicam na tecnologia streaming. Assim, igualmente analisa o funcionamento do streaming, até sua chegada ao usuário, além de perquirir sobre os critérios materiais do ICMS - Comunicação e do ISSQN. Adota o método hipotético-dedutivo, bem como o bibliográfico para a pesquisa, procedendo com a comparação dos elementos investigados na doutrina e jurisprudência, dividida nas fases de levantamento e análise. Conclui que, pela moderna visão dos conceitos de prestação de serviço é

* Artigo apresentado ao Curso de Bacharelado em Direito do Centro Universitário Metodista - IPA, como requisito parcial para obtenção do Grau de Bacharel em Direito.

** Graduando do Curso de Bacharelado em Direito do Centro Universitário Metodista - IPA.

*** Orientador do artigo, Especialista em Direito Empresarial, Mestre e Doutor em Direito pela Universidade Federal do Rio Grande do Sul e professor do Curso de Bacharelado em Direito do Centro Universitário Metodista - IPA. 
possível enquadrar a tecnologia streaming na hipótese de incidência do imposto municipal, bem como, não possibilita a cobrança do imposto, caso adotada a corrente doutrinária que vincula a tributação apenas nas obrigações de "fazer". Igualmente não incide no imposto estadual, por se tratar de um serviço de valor adicionado.

Palavras-chave: Streaming. ICMS. ISSQN. Imposto.

\section{DIGITAL TAXATION:ANALYSIS ON THE INCIDENCE OF ICMS AND ISSQN IN STREAMING TECHNOLOGY}

\section{ABSTRACT}

The Streaming has taken on a great deal of space in the economy and also in the social life of Brazilians, since the second decade of the 21st century, consisting of one of the new forms of consumption of digital material. In view of this phenomenon, this article aims to investigate the nature of the new technology, in order to verify the possibility of its incidence on the Tax on the Circulation of Commodities and Service (ICMS) and / or the Tax on Services of any kind (ISSQN). It points out the doctrine's understanding of the mentioned taxes, in order to verify if the hypotheses of incidence of both are applied in the technology streaming. Thus, it also analyzes the operation of the streaming, until its arrival to the user, in addition to investigate the material standard of the ICMS - Communication and the ISSQN. It adopts the hypothetical-deductive as well as the bibliographic method for the research, proceeding with the comparison of the elements investigated in the doctrine and jurisprudence, divided in the phases of survey and analysis. It concludes that by the modern vision of the concepts of "service provision" it is possible to frame the streaming technology in the hypothesis of incidence of the municipal tax. As well as, it does not allow the collection of the tax, if adopted the doctrinal current that links the taxation only in the obligations of "to do". Equally, it does not affect the state tax, since it is a value-added service.

Key words: Streaming. ICMS. ISSQN. Tax.

\section{INTRODUÇÃO}

Diante de um cotidiano onde as interações e comunicações humanas se realizam, em grande parte, através do mundo digital, pode-se perceber um avanço expressivo nas demandas tecnológicas. A busca por dinamização e formas acessíveis de conteúdo, moldam os interesses de novos usuários. A partir deste ambiente 
propício para novidades no mercado, o streaming surge como uma nova forma de atender este almejo social.

Entretanto, os progressos científicos evoluem de modo mais rápido que a adequação legislativa. Logo, faz-se necessário a criação de incidência normativa sobre o mundo fático, enquadrando assim, as novidades tecnológicas em meios tributáveis, ou ainda, adaptar aos meios já existentes no ordenamento, a fim de explorar suas capacidades de contribuição.

Nesse plano, o streaming levantou diversos questionamentos em sua forma contributiva, uma vez que passou a ser tributado por dois impostos de competências diversas. À vista desse fenômeno, necessita-se de uma investigação da natureza da nova tecnologia, a fim de verificar a possibilidade de sua incidência no Imposto Sobre Circulação de Mercadoria e Serviço (ICMS) ou no Imposto Sobre Serviços de Qualquer Natureza (ISSQN).

O intuito deste artigo é precisamente apontar a concepção que a doutrina dispõe sobre os impostos mencionados, a fim de verificar se as hipóteses de incidência de ambos se aplicam na tecnologia streaming. Para isso, o artigo tende a analisar o funcionamento do streaming, até sua chegada ao usuário, além de perquirir sobre os critérios materiais do ICMS - Comunicação e do ISSQN.

\section{O STREAMING}

O Streaming, é uma tecnologia que vem sendo muito utilizada pelas grandes marcas atuantes no mercado de entretenimento. Ela permite a transmissão de conteúdo multimídia através da internet, sem que o usuário necessite armazenar os arquivos de maneira definitiva, como ocorre no download.

A fim de definir de maneira objetiva e razoável para fins jurídicos, sem fugir das formas técnicas de formação da tecnologia, o Ministro Ricardo Villas Bôas Cueva apresenta em um de seus votos como relator, a visão de que: 
Streaming é a tecnologia que permite a transmissão de dados e informações, utilizando a rede de computadores, de modo contínuo. Esse mecanismo caracteriza-se pelo envio de dados por meio de pacotes, sem que o usuário realize download dos arquivos a serem executados. [...] Desse modo, a tecnologia de streaming permite a transferência de áudio ou vídeo em tempo real sem que o usuário conserve uma cópia do arquivo digital em seu computador, e é exatamente nesse ponto que reside a mudança de paradigma, pois, diferentemente do que acontecia há poucos anos, hoje, o que importa é o acesso, e não mais a propriedade ou a posse da mídia física (seja vinil, CD ou qualquer outra forma de corporificação da obra) ou virtual. ${ }^{1}$

O conceito de "Streaming" é construído a partir da palavra da língua inglesa "Stream", que significa córrego ou corrente ${ }^{2}$. Na linguagem da computação e da internet, a expressão exprime a ideia de fluxo ou sucessão ${ }^{3}$. Razão pela qual sua morfologia constrói-se a partir da abstração de que a tecnologia funciona como uma corrente que leva o conteúdo do servidor até o receptor de quem a consome de maneira contínua e sem interrupções.

Entretanto, a partir de seu conceito, não se pode assumir que a tecnologia streaming possua um ponto inicial para seu funcionamento. Ela não opera de maneira independente, necessitando assim de um intermediário para seu exercício. Portanto, o encetamento da atividade ocorre por meio da Internet. A Internet será o meio, ou canal, que suportará e garantirá o pleno funcio-

$1 \quad$ BRASIL. Superior Tribunal de Justiça. Recurso Especial $\mathbf{n}^{\circ} 1559264$ RJ. Relator: Ministro Ricardo Villas Bôas Cueva, Pesquisa de Jurisprudência, Acórdãos, 08 fev. 2017. Disponível em: <http://www.stj.jus.br>. Acesso em: 02 jun. 2018.

2 Google tradutor. Google.com. Disponível em < https://translate.google.com. br/?hl=pt-BR\#en/pt/stream >. Acesso em: 02 jun. 2018.

3 SAWAYA, Márcia Regina. Dicionário de informática \& Internet. NBL Editora, 1999. p.449. 
namento da tecnologia streaming. Ela é o produto disponibilizado pelo serviço de telecomunicação, sendo esse o ponto de partida responsável pelo tráfico de dados em que atuará o Streaming.

Com o advento da banda larga e o aumento da velocidade dos provedores, o streaming ganhou ainda mais popularidade. Hoje, a tecnologia já sustenta diversas plataformas em múltiplos seguimentos, conduzindo um destaque para as transmissões de música e filmes. Conforme aponta a pesquisa realizada pela Federação Internacional da Indústria Fonográfica, o streaming de música se tornou em $2017^{4}$ a principal fonte de renda do setor musical, representando já 38,4\% do total das receitas ${ }^{5}$.

Como já mencionado, a velocidade é um dos principais pilares que popularizou a tecnologia, uma vez que a transferência não necessita ser completa para permitir que os consumidores tenham acesso ao seu conteúdo. De modo instantâneo, é possível iniciar o consumo dos produtos oferecidos pela tecnologia, devido a sua transmissão ocorrer pelo sistema de "buffering".

Como explica Marcia Regina Sawaya, o buffering é uma:

Técnica de programação utilizada para compensar a velocidade lenta, e muitas vezes sujeita a uma alta taxa de erros, de um dispositivo periférico. Se o dispositivo se comunica diretamente com o programa, este se limita a trabalhar sincronizado com o referido programa. Esta técnica possibilita que o programa e o dispositivo operem independentes. ${ }^{6}$

4 Ressalva-se que este estudo de 2017 foi o mais atualizado em relação ao tema.

5 Portal G1. Globo. Streaming de música torna-se principal fonte de renda do setor pela $1^{\text {a }}$ vez, diz relatório. Brasil, 2018. Disponível em < https:// g1.globo.com/pop-arte/musica/noticia/streaming-de-musica-torna-se-principal-fonte-de-renda-do-setor-pela-1-vez-diz-relatorio.ghtml> Acesso em 02 jun. 2018.

6 SAWAYA, Márcia Regina. Dicionário de informática \& Internet. NBL Editora, 1999. p. 60. 
Em outras palavras, esse processo permite transferências de pré-carregamento. Ou seja, o streaming consiste em um fornecimento multimídia de modo que o usuário pode fazer o carregamento dos arquivos ao mesmo tempo em que já está assistindo, sendo esse um grande triunfo sobre seu percursor, a tecnologia de download. Anteriormente, os conteúdos oferecidos pelas empresas, necessitavam de um armazenamento no sistema do usuário para a posterior reprodução.

Os serviços de streaming são oferecidos no mercado de consumo de duas formas predominantes. A primeira delas, utilizada comumente por meios de comunicação de televisão e rádio, é popularmente conhecido como "live streaming", ou "streaming em tempo real”. Nessa forma, Behrouz A. Forouzan relata que simplesmente ocorre quando "um usuário ouve uma transmissão de áudio ou vídeo pela internet"7. 0 protocolo utilizado nesse método é o RTSP (Real Time Streaming Protocol), onde não é necessário nenhum tipo de armazenamento em servidores. Assim, a receptação do conteúdo ocorre simultaneamente com a sua produção, igualmente aos programas televisivos e de radiodifusão que produzem conteúdo "ao vivo".

Uma forma que também é manipulada pelo RTSP, entretanto, ainda não utilizada de forma tão expressiva no mercado de consumo, é o "streaming interativo em tempo real". Ele normalmente é utilizado em videoconferências e programas que interagem com os usuários, muita das vezes conectados pelas redes sociais.

Em contrapartida, a segunda forma predominante, fornece o conteúdo já produzido conforme a demanda do usuário e necessita de um prévio armazenamento em servidores. A técnica de armazenamento é a forma mais popular entre as empresas que reproduzem a tecnologia, sendo elas as grandes sucessoras de serviços comumente prestados pelas vídeo-locadoras e varejos musicais.

FOROUZAN, Behrouz A. Protocolo TCP/IP [recurso eletrônico]. Tradução: João Eduardo Nóbrega Tortello. 3. ed. Porto Alegre: AMGII, 2010. p. 652. 
O streaming de armazenamento ou também conhecidos no mercado pela expressão "on demand", como explica Behrouz A. Forouzan, são arquivos que foram "compactados e armazenados em um servidor" ${ }^{\prime \prime}$. Cabe salientar que o armazenamento do conteúdo multimídia pode ser feito em servidores independentes de quem possui a tecnologia de streaming, podendo também ser armazenada, em parte no próprio receptor tecnológico do usuário.

\subsection{A ESTRUTURA INTERMEDIARIA DA TECNOLOGIA STREAMING}

Com o emergente mercado de produtos tecnológicos do século XXI, os setores atuantes no desenvolvimento de produtos e serviços disponibilizados via internet, desenvolveram seus projetos visando o aumento no consumo pelo oferecimento de um amplo conteúdo de sua temática em custo relativamente baixo. Por consequência, a tecnologia streaming passou a ser adotada por um número expressivo de empresas, com a pretensão de oferecer serviços já presentes no mercado, entretanto de maneira digital, através da internet.

A internet, que ainda é uma região pouco explorada, pois carrega um vasto campo de incertezas, onde seus produtos sofrem constates mutações, atualizações e não possuem formas definitivas, podendo interagir e se adequar a diversas realidades, já assume diante de nosso mundo globalizado, uma das maiores plataformas de acesso a comunicação. Carrega consigo, formas de cultura, de entretenimento e de tantos outros âmbitos socialmente relevantes para a coletividade.

David Tuner e Jesus Muñoz acreditam que:

Traduzido do inglês: "por demanda".

FOROUZAN, Behrouz A. Protocolo TCP/IP [recurso eletrônico]. Tradução: João Eduardo Nóbrega Tortello. 3. ed. Porto Alegre: AMGII, 2010. p. 651. 
A Internet não é um novo meio de comunicação. Ela irá se converter rapidamente no meio de comunicação. A Internet no futuro (...) será um sistema integral de multimídia que acessará todos os jornais, revistas, emissoras de rádio, canais de televisão e filmes produzidos por todos os países do mundo. ${ }^{10}$

Ainda que este futuro definido pelos autores não esteja tão distante, a autora Elidie Palma Bifano defende que atualmente "a Internet é uma rede virtual, logo, representada a todo o momento, que interliga computadores permitindo que um equipamento possa acessar documentos ou arquivos de outro"11.

Com o propósito de estabelecer a ligação entre os usuários, cada dispositivo que permite a conexão com a Internet possui um protocolo, que também pode ser definido como um endereço do terminal. Esse protocolo recebe o nome de IP e possui seu conceito definido no artigo $5^{\circ}$, III da Lei 12.965/14. Para fins legais, a Lei o define como sendo "o código atribuído a um terminal de uma rede para permitir sua identificação, definido segundo parâmetros internacionais."

Precisamente, a Lei 12.965/14, também conhecida por Marco Civil da Internet, reproduz em seu artigo $5^{\circ}$, inciso I, que a Internet é "o sistema constituído do conjunto de protocolos lógicos, estruturado em escala mundial para uso público e irrestrito, com a finalidade de possibilitar a comunicação de dados entre terminais por meio de diferentes redes."

Logo, a partir de sua definição legal, entendemos que a Internet propicia ao receptor o alcance aos dados de um emissor, assumindo a forma de um canal comunicacional. Podemos admitir, a partir desse entendimento, que todo o procedimento envolto

10 TURNER, David; MUÑOZ, Jesus. Para os filhos dos filhos dos nossos filhos: Uma visão da sociedade Internet. Plexus. São Paulo, v. 1, 2002. p. 66.

11 BIFANO, Elidie Palma. 0 negócio eletrônico e o sistema tributário brasileiro. São Paulo: Quartier Latin, 2004. p. 99. 
para o pleno funcionamento da tecnologia streaming necessariamente inicia tendo a Internet como meio capaz de suportar as transmissões.

A comunicação de dados, realizados pelas redes, são padronizadas por dois parâmetros definidos pelas entidades internacionais, sendo eles o RMI-OSI (Reference Model for Open System Interconnection) produzido pela International Standards Organization (ISO) e o TCP/IP, o qual assume o sustentáculo de operação da Internet, projetado pelo departamento de defesa dos Estados Unidos ${ }^{12}$.

$\mathrm{O}$ modelo TCP/IP possui níveis que definem sua arquitetura, dividindo-se em quatro grandes camadas. A primeira é chamada de camada física, onde encontramos a infraestrutura da telecomunicação, onde estão presentes os transceptores e cabos que fazem as conexões via satélite e de rádio terrestre. A segunda camada é a Inter-Rede, é nela que a transferência e a união de dados são realizadas. A capacidade de assegurar o tráfego de dados é feita pela terceira camada, denominada de camada de transporte.

A quarta e última camada deste modelo é a camada de aplicação, equivalente a sétima camada do modelo RM-OSI. É nessa camada que está contido os sites da Web, os aplicativos e as plataformas. É nela que encontramos também a atuação da tecnologia streaming.

No Brasil, para que o consumidor tenha acesso à Internet, se faz necessário a contratação de um Provedor de Acesso ou também conhecido como Provedor de Conexão. Os Provedores são pessoas jurídicas que fornecem a ligação dos terminais à Internet, por meio de contratos, geralmente de adesão, aos usuários. Assim também podemos defini-lo nas palavras de José Wilson Ferreira Sobrinho como a "chave que destranca a porta da internet"13.

12 BRITO, Samuel Henrique Bucke. Análise de negócios na oferta do serviço de TV digital via IP (IPTV) no Brasil. Dissertação (Mestrado em Engenharia Elétrica) - Pontifícia Universidade Católica de Campinas, Campinas, 2008. p. 37.

13 FERREIRA SOBRINHO, José Wilson. Direito tributário: temas pontuais. Rio de Janeiro: Forense, 2001. p. 182. 
Cabe salientar que os Provedores não se confundem com os meios físicos de suporte material da internet, uma vez que, essa função compete ao serviço de telecomunicação.

Como define a autora Eliana Calmon:

\begin{abstract}
Com efeito, agem os provedores como monitores ou facilitadores do usuário, colocando à disposição dos seus clientes equipamentos e softwares que dão acesso e facilitam a utilização do sistema, mas, em verdade, são ambos, provedores e usuários, tomadores do serviço de comunicação, cujo suporte maior e imprescindível é o serviço de telecomunicação. ${ }^{14}$
\end{abstract}

O serviço de telecomunicação, definido pela Lei Geral de Telecomunicações (LGT) em seu artigo 60, "é o conjunto de atividades que possibilita a oferta da telecomunicação". Ou seja, é através desse serviço, indispensável, que suportará o canal comunicacional (Internet), servirá de estrutura para os provedores e por consequência, viabilizará o processo de funcionamento da tecnologia streaming.

Incumbe ao serviço de telecomunicação, segundo a Lei $\mathrm{n}$ o 9.472/97, a "transmissão, emissão ou recepção, por fio, radioeletricidade, meios ópticos ou qualquer outro processo eletromagnético, de símbolos, caracteres, sinais, escritos, imagens, sons ou informações de qualquer natureza". Assim, ocupa o papel de meio físico e propagador, no qual é necessário para estabelecer a conexão de internet e possibilitar qualquer serviço que dela se utilize como meio.

A conceituação de novos serviços no mercado de consumo, demandam um estudo aprimorado sobre toda a cadeia estrutural de sua operação. Por isso, é de fundamental relevância que

14 CALMON, Eliana. Informativo Jurídico da Biblioteca Ministro Oscar

Saraiva. v. 15, n. 2, p. 137-265, Jul/Dez. 2003 p. 233. 
o processo de funcionamento esteja descrito e bem situado em sua devida repartição.

\section{DO FENÔMENO DA INCIDÊNCIA TRIBUTÁRIA}

A partir da teoria kelseniana, a estruturação de nosso ordenamento jurídico "não é um sistema de normas jurídicas ordenadas no mesmo plano, situada umas ao lado das outras, mas é uma construção escalonada de diferentes camadas ou níveis de normas jurídicas"15. Nele, o sistema normativo é criado a partir de complexas experiências e alicerçadas em convicções baseadas no mundo fático. Podemos admitir que as normas que o compõe, visam a garantia de segurança jurídica e viabilização na promoção de direitos fundamentais.

Alicerçado nessa ordenação multifacetada, Humberto Ávila descreve que:

As regras são normas imediatamente descritivas, primariamente retrospectivas e com pretensão de decidibilidade e abrangência, para cuja aplicação se exige a avaliação da correspondência, sempre centrada na finalidade que lhes dá suporte ou nos princípios que lhe são axiologicamente sobrejacentes, entre a construção conceitual da descrição normativa e a construção conceitual dos fatos. ${ }^{16}$

As normas, bem como os princípios que ocupam o plano pelos quais traduzem o espaço jurídico para o campo da ética ${ }^{17}$, formam este complexo ordenamento. Ainda nessa visão, o professor Miguel Reale ensina que:

15 KELSEN, Hans. Teoria pura do direito. 6. ed. Tradução de João Baptista Machado. São Paulo: Martins Fontes, 1998. p. 247.

16 ÁVIlA, Humberto. Teoria dos Princípios. 9ạ ed. São Paulo: Editora Malheiros, 2009. p.78.

17 BARROSO, Luís Roberto. A nova interpretação constitucional: ponderação, direitos fundamentais e relações privadas. $3^{a}$ ed. - Rio de Janeiro: Renovar, 2008. p.203. 
[...]o legislador, por conseguinte, é o primeiro a reconhecer que o sistema das leis não é suscetível de cobrir todo o campo da experiência humana, restando sempre grande número de situações imprevistas, algo que era impossível ser vislumbrado se quer pelo legislador no momento da feitura da lei. Para essas lacunas há a possibilidade do recurso aos princípios gerais do direito, mas é necessário advertir que a estes não cabe apenas essa tarefa de preencher ou suprir as lacunas da legislação. ${ }^{18}$

O sistema constitucional tributário, busca suprir de forma legal e principiológica, a regulação das condutas humanas. Para isso, o legislador pondera ideias e deduz hipóteses, com a intenção de condicioná-las em implicações reais, daquilo que é frequente no mundo fático. Nesse sentido, Geraldo Ataliba explica que a "hipótese de incidência é a descrição hipotética e abstrata de um fato. É parte da norma tributária. É o meio pelo qual o legislador institui um tributo. Está criado um tributo, desde que a lei descreva sua hipótese de incidência, a ela associando o mandamento 'pague'”19.

Assim, observamos que "a hipótese alude a um fato e a consequência prescreve os efeitos jurídicos que o acontecimento irá propagar" 20 , conforme descreve Paulo de Barros Carvalho em sua obra. 0 mesmo autor, ainda prevê que:

Na hipótese (descritor), haveremos de encontrar um critério material (comportamento de uma pessoa), condicionado no tempo (critério temporal) e no espaço (critério espacial). Já na conseqüência (prescritor), depararemos com um critério pessoal

18 REALE, Miguel. Lições preliminares de direito. São Paulo: Saraiva, 2002. p.304.

19 ATALIBA, Geraldo. Hipóteses de Incidência Tributária. São Paulo: Malheiros, 2009. p. 66.

20 CARVALHO, Paulo de Barros. Curso de direito tributário. 17. ed. São Paulo: Saraiva, 2005. p. 242. 
(sujeito ativo e sujeito passivo) e um critério quantitativo (base de cálculo e alíquota). ${ }^{21}$

Os critérios sobre as hipóteses de incidência apresentado pelo autor, conduzem a interpretação do legislador para enquadramento do mundo real com um determinado tributo. Assim o faz, restringindo o exercício da competência, para que então não viole o sistema tributário. Ao apontar os limites para o legislador tributário, a Constituição, ainda que propicie determinada autonomia pela norma-padrão de incidência, modelou um determinado espaço para que este não ultrapasse o padrão normativo constitucional ${ }^{22}$.

Diante dessa restrição, o Código Tributário Nacional em seu artigo 110, expressa a ideia de que a legislação tributária não poderá alterar a definição de conceitos de direito privado contidos na Constituição Federal. Surge então, a partir desse texto legal o entendimento de que o ordenamento jurídico tributário pode ser interpretado de forma sistemática.

Necessário ressaltar a importância da utilização da regra matriz de incidência tributária, uma vez que o Vitório Cassone reforça:

A esquematização formal da regra-matriz de incidência tem-se mostrado um utilíssimo instrumento científico, de extraordinária fertilidade e riqueza para a identificação e conhecimento aprofundado da unidade irredutível que define a fenomenologia básica da imposição tributária. Seu emprego, sobre ser fácil, é extremamente operativo e prático, permitindo, quase que de forma imediata, penetrarmos na secreta intimidade da essência normativa, devassando-a e analisando-a de maneira

21 CARVALHO, Paulo de Barros. Curso de direito tributário. 17. ed. São Paulo: Saraiva, 2005. p. 243.

22 CARRAZZA, Roque Antonio. ICMS. 9. ed. São Paulo: Malheiros, 2005. p. 3132. 
minuciosa. Em seguida, experimentando o binômio base de cálculo/hipótese de incidência, colhido no texto constitucional para marcar a tipologia dos tributos, saberemos dizer, com rigor e presteza, da espécie e da subespécie da figura tributária que investigamos. ${ }^{23}$

Portanto, este artigo visa a análise da tecnologia streaming diante do tributo estadual e municipal, sob a análise de suas regras-matriz de incidência.

\subsection{OS CRITÉRIOS DAS HIPÓTESES DE INCIDÊNCIA TRIBU- TÁRIA}

Em primazia, no plano descritor, o critério material estará sempre ligado ao verbo nuclear. Ele será o elemento tipificador. Geraldo Ataliba descreve que "este aspecto dá, por assim dizer, a verdadeira consistência da hipótese de incidência. Contém a indicação de sua substância essencial, que é o que de mais importante e decisivo há na sua configuração"24. Após a reprodução do verbo nuclear do primeiro critério, surgirá o segundo denominado de critério temporal.

Esse estará vinculado ao momento em que se realiza e surge a obrigação. Para Paulo de Barros Carvalho, o critério temporal é "o grupo de indicações, contidas no suposto da regra, e que nos oferecem elementos para saber, com exatidão, em que preciso instante acontece o fato descrito, passando a existir o liame jurídico que amarra devedor e credor, em função de um objeto - o pagamento de certa prestação pecuniária"25.

O terceiro critério, ou também chamado por Geraldo Ataliba

23 CASSONE, Vitório. Direito Tributário. 19. ed. São Paulo: Atlas, 2008. p. 420.

24 ATALIBA, Geraldo. Hipóteses de Incidência Tributária. São Paulo: Malheiros, 2009. p. 106.

25 CARVAlHO, Paulo de Barros. Curso de Direito Tributário. São Paulo: Saraiva, 2010.p.327. 
de aspecto espacial representa "a indicação de circunstâncias de lugar - contidas explicita ou implicitamente na hipótese de incidência - relevantes para a configuração do fato imponível"26. Assim, sua função está na demarcação de um determinado local em que ocorrerá o fato gerador da obrigação tributária.

Avançando para o plano prescritor, deparamo-nos com mais dois critérios: o pessoal e o quantitativo. 0 primeiro, se refere aos polos integrantes da obrigação tributária. Sendo que "o aspecto pessoal é o atributo da hipótese de incidência que determina o sujeito ativo da obrigação tributária respectiva e estabelece os critérios para fixação do sujeito passivo"27. Já o segundo, traz a ideia de determinar o quantum, por meio da base de cálculo e da alíquota, que o tributo está revestido. Geraldo Ataliba explica que é sempre possível calcular a hipótese definida, reduzindo ela a números de expressão valorada ${ }^{28}$.

A fim de explicar sua abrangência, Paulo de Barros Carvalho complementa ao expor que:

\begin{abstract}
Uma das funções da base de cálculo é medir a intensidade do núcleo factual descrito pelo legislador. Para tanto, recebe a complementação de outro elemento que é a alíquota, e da combinação de ambos resulta a definição do debitum tributário. Sendo a base de cálculo uma exigência constitucionalmente obrigatória, a alíquota, que com ela se conjuga, ganha, também, foros de entidade indispensável. Carece de sentido a existência isolada de uma ou de outra. ${ }^{29}$
\end{abstract}

26 ATALIBA, Geraldo. Hipótese de incidência tributária. 5ª ed. São Paulo: Malheiros Editores, 1995. p.93.

27 ATALIBA, Geraldo. Hipóteses de Incidência Tributária. São Paulo: Malheiros, 2009. p. 82.

28 ATALIBA, Geraldo. Hipóteses de Incidência Tributária. São Paulo: Malheiros, 2009. p. 109.

29 CARVALHO, Paulo de Barros. Curso de Direito Tributário. São Paulo: Saraiva, 2010. p. 392. 
Uma vez que os critérios possuem tipicidade cerrada, pois estão abarcados pelo princípio da estrita legalidade, impedem que o aplicador da norma se envolva nas suas diretrizes ao realizar suas interpretações ${ }^{30}$. Assim, a partir de uma visão sob os aspectos caracterizadores da hipótese de incidência tributária, poderemos analisar a possibilidade da tecnologia streaming estar abrangida pelo tributo estadual ou municipal.

\section{DO SERVIÇO}

Uma vez que necessário para identificar se há adequação com a hipótese de incidência disposta pelo legislador no ICMS e no ISSQN, a conceituação de serviço é vital para o desenvolvimento desse artigo. 0 direito, na condição de ciência, compreende vocábulos que comprovam a harmonização com seus institutos e assim revelam a importância de estarem apurados pela doutrina e jurisprudência. Assim, reforça Norberto Bobbio ao sustentar que:

As questões de nome são de grande importância, porque, elegendo um nome ao invés de outro, torna-se rigorosa e não suscetível de mal-entendido uma determinada linguagem. A purificação de linguagem é uma parte essencial da pesquisa científica, sem a qual nenhuma pesquisa poderá dizer-se científica. ${ }^{31}$

Se examinarmos apenas a forma morfológica, alcançaremos que a definição de serviço "é o ato ou efeito de servir, de dar de si

30 COÊLHO, Sacha Calmon Navarro. Curso de Direito Tributário Brasileiro. 6.ed. Rio de Janeiro: Forense, 2001. p. 200.

31 BOBBIO, Norberto. Studi Sulla Teoria Generale del Diritto. Giappichelli, 1955, p. 37. apud BRASIL. Supremo Tribunal Federal. Recurso Extraordinário $n^{\circ}$ 166.772. Relator: Ministro Marco Aurélio. Pesquisa de Jurisprudência, Acórdãos, 12 mai. 1994. Disponível em:< http://redir. stf.jus.br/paginadorpub/paginador.jsp?docTP=AC\&docID=216095> Acesso em: 10 dez. 2018. 
algo em forma de trabalho"32. Entretanto, a forma usual da palavra não equivale à mesma conceituação jurídica imposta a ela, necessitando então da classificação de seu conceito no direito positivo.

Em verdade, o âmbito jurídico diverge em definir o conceito de serviço, uma vez que sua incidência não se dá apenas no direito tributário, podendo abarcar múltiplas áreas legais, como no plano trabalhista, concebendo então um entendimento diferenciado. Logo, cabe à doutrina definir a semântica linguística para então aplicar apropriadamente na norma de incidência.

A concepção de trabalho no ordenamento jurídico possui uma amplitude superior a ideia de serviço, os textos constitucionais vinculam seu conceito de modo genérico a uma obrigação de fazer. A vista disso, é necessário entender a delimitação do conceito de serviço, no qual estará inserido no domínio do trabalho, funcionará como uma espécie dentro de seu gênero. Assim, não será todo liame obrigacional de fazer que atingirá o intelecto de serviço, pois este encontra-se mais restrito em seu plano ${ }^{33}$.

No mesmo sentido, ATALIBA define que:

O serviço é sempre uma atividade humana, prestada para outra pessoa, produzindo em seu favor uma utilidade material. É a partir desse conceito que se pode chegar ao de "serviço tributável", ou seja, a determinação daquele campo demarcado por este conceito, juridicamente qualificado - pela Constituição - como passível de sofrer tributação. ${ }^{34}$

Portanto, ao traçar uma delimitação jurídica para o conceito de serviço, tendo a obrigação vinculada ao seu termo, uma obri-

32 HOUAISS, Antônio; VILLAR, Mauro; DE MELLO FRANCO, Francisco Manoel. Dicionário Houaiss da língua portuguesa. 2001. p. 2.559.

33 BARRETO, Aires F. ISS na Constituição e na Lei. São Paulo: Dialética, 2003. p. 29.

34 ATALIBA, Geraldo; BARRETO, Aires F. ISS-Locação e leasing. Revista de Direito Tributário, v. 14, n. 51,1990, São Paulo, p. 52. Grifo do original. 
gação de "fazer" e não excedendo os limites do direito privado, é possível inseri-lo no âmbito tributável.

A conceituação de serviço, pressupõe uma relação entre dois polos, onde é necessário o surgimento de um liame obrigacional. Uma vez que a relação jurídica só se materializará quando a prestação for em favor de outra pessoa, diferente do conceito de trabalho, no qual é possível que se substancialize em favor próprio, sem relação com terceiros ${ }^{35}$.

Para o Professor Aires Fernandino Barreto, serviço objetiva-se em ser "a prestação de esforço humano a terceiros, com conteúdo econômico, em caráter negocial, sob regime de direito privado, tendente à obtenção de um bem material ou imaterial"36. Admitindo a percepção do autor, ao adotar o regime privado, acaba por excluir os serviços prestados de forma subordinada sob o poder do empregador, bem como os serviços públicos.

Ainda que parte da doutrina se preocupe em alocar a concepção de serviço dentro do Direito Privado, Hugo de Brito Machado acredita que:

Não é necessário que o conceito de serviço esteja no Direito Privado. Muito menos que ele esteja definido em norma do Direito Privado. Para que ele não possa ser alterado pelo legislador tributário basta que esteja - como está - na Constituição Federal, pois sua alteração pelo legislador implica evidente alteração da norma da Constituição na qual está albergado. ${ }^{37}$

35 BARRETO, Aires F. ISS na Constituição e na Lei. São Paulo: Dialética, 2003. p. 29.

36 BARRETO, Aires Fernandino. ISS-Atividade-meio e serviço-fim. Revista Dialética de Direito Tributário. v. 5, p. 72-97, 1996. p. 78.

37 MACHADO, Hugo de Brito. Curso de direito tributário. 28. ed. Malheiros, 2007. p. 422. 
Já no entendimento apontado pela jurisprudência e a doutrina recente a edição deste artigo, a concepção de serviço passa a abranger novas formas a fim de atender o progresso tecnológico. Nessa vertente, o ex-Ministro Joaquim Barbosa, sustenta que:

[...] a rápida evolução social tem levado à obsolescência de certos conceitos jurídicos arraigados, que não podem permanecer impermeáveis a novas avaliações (ainda que para confirma-los). Ideias como a obrigação de "dar" e "fazer" desafiam a caracterização de operações nas quais a distinção dos meios de formatação do negócio jurídico cede espaço as funções econômica e social das operações e a postura dos sujeitos envolvidos (e.g.,software as servisse, distribuição de conteúdo de entretenimento por novas tecnologias). Cabe aqui ponderar a influência do princípio da neutralidade da tributação". ${ }^{38}$

À vista disso, podemos observar uma construção moderna ao conceito de serviço, onde não estaremos mais diante de uma obrigação unicamente de "fazer" e sim de "dar". Visto que é necessário o acompanhamento do conceito jurídico com as dinamizações no mercado de consumo. Em verdade, o ex-Ministro atenta para a importância da obrigação, uma vez que a natureza dos bens entregues pelas novas formas tecnológicas, em sua maioria, se constitui em bens infungíveis e incorpóreos.

\section{DO ICMS-COMUNICAÇÃO}

O ICMS é a abreviação dada ao imposto sobre operações relativas à circulação de mercadorias e prestação de serviços, isto é, um imposto predominantemente fiscal de recolhimento

38 BRASIL. Supremo Tribunal Federal. Recurso Extraordinário no 547.245. Relator: Ministro Eros Grau. Pesquisa de Jurisprudência, Acórdãos, 02 dez. 2009. Disponível em:<<http://redir.stf.jus.br/paginadorpub/paginador. jsp?docTP=AC\&docID=609062> Acesso em: 02 jun. 2018. 
dos Estados e do Distrito Federal, conforme o mandamento Constitucional:

Artigo 155. Compete aos Estados e ao Distrito Federal instituir impostos sobre:

[...]

II - operações relativas à circulação de mercadorias e sobre prestações de serviços de transporte interestadual e intermunicipal e de comunicação, ainda que as operações e as prestações se iniciem no exterior;

Entretanto, apenas com a definição legal do artigo 155 da Constituição Federal de 1988, não é possível identificar e detalhar o significado de "prestação de serviço de comunicação", objeto de estudo deste trabalho, a fim de balizar a aplicação de sua incidência nos serviços de streaming.

Para identificar as características do mandamento constitucional e assim afirmar se é possível ou não a aplicação do imposto na prestação de serviço por streaming, passamos a uma análise do termo prestação de serviço. Ainda que já abordado neste artigo a nova corrente de entendimento do conceito de serviço, onde surge também a partir de obrigações de dar, é possível extrair do vocábulo propriedades inclusas pela doutrina jurídica. Nesse sentido, Marco Aurélio Greco e Anna Paola Zonari dizem que:

\begin{abstract}
Na medida em que a CF-88 atinge "serviços", que é conceito com perfil jurídico definido, isto implica ter sido alcançado apenas um determinado tipo de atividade que seja objeto de contratação especifica mediante remuneração (prestação de utilidade). ${ }^{39}$
\end{abstract}

39 GRECO, Marco Aurélio, ZONARI, Anna Paula. ICMS - Materialidade e princípios constitucionais. In: MARTINS, Ives Granda da Silva (Coord.). Curso de direito tributário. 2. Ed. Belém: CEJUP, v. 2, 1993. p. 150. 
$\mathrm{Na}$ mesma linha de pensamento, André Mendes Moreira ${ }^{40}$, presume que o legislador constitucional, ao reconhecer a natureza negocial para a incidência do imposto, se faz necessária uma retribuição para o serviço prestado, apresentando então um critério oneroso, indispensável, ao instituto. Admitindo a oneração como um dos critérios substanciados no conceito de serviço, é possível observar que o legislador ao editar as normas gerais, pela Lei Complementar $n^{\circ} 87 / 1996$, está obrigatoriamente vinculando a onerosidade nos serviços:

Art. $2^{\circ} 0$ imposto incide sobre:

[...]

III - prestações onerosas de serviços de comunicação, por qualquer meio, inclusive a geração, a emissão, a recepção, a transmissão, a retransmissão, a repetição e a ampliação de comunicação de qualquer natureza;

Em que pese o caráter oneroso seja necessário para a incidência do ICMS-Comunicação, ele não é o único imprescindível. É de fundamental importância que a prestação de serviço seja conferida de maneira mútua, com dois polos vinculados por uma relação jurídica, necessitando assim, de dois particulares para sua concretização $0^{41}$. Diante disso, teremos duas figuras distintas para prestação do serviço, aquela que de maneira onerosa remunerará (tomador) pela atividade recebida, e aquela que prestará a obrigação contratada (prestador), trazendo assim as características da bilateralidade.

Apesar da importância do caráter bilateral, para a incidência do imposto, este necessita estar revestido de um caráter negocial. Nesse sentido, Roque Antonio Carrazza declara que “o tributo

40 MOREIRA, André Mendes. A tributação dos serviços de comunicação. Dialética, 2006. p. 95.

41 CORAZZA, Edison Aurélio. ICMS sobre prestações de serviços de comunicação. São Paulo: Quartier Latin, 2006. p.54. 
em questão pressupõe, para nascer in concreto, a realização de negócio jurídico que tenha por objeto a prestação de um serviço de comunicação" ${ }^{42}$. É nessa forma que encontramos os serviços "on demand" de maior expressão no mercado, como a Netflix e o Spotify.

A Netflix é uma empresa que oferece, ao usuário contratante e mediante a utilização da internet, uma gama de filmes e séries para visualização através de aparelhos de reprodução multimídia ${ }^{43}$. Já o Spotify, é uma empresa que apresenta um serviço semelhante, entretanto, no setor musical. Ele fornece, aos seus assinantes, uma licença que concede a detenção da propriedade de seus conteúdos de forma limitada e temporária ${ }^{44}$.

Excluindo a modalidade gratuita, ambos possuem a adesão de um contrato, onde há uma retribuição em forma de pecúnia, caracterizado pelo pagamento das mensalidades. Fenômenos que tipificam o caráter negocial.

Cabe destacar, a partir dos critérios materiais apresentados, que se exclui da incidência de tributação pelo ICMS-Comunicação, os serviços de streaming prestados de maneira gratuita, uma vez que não apresentam contraprestação à atividade oferecida. Não agregando assim o caráter negocial.

Nesse sentido, Roque Antonio Carrazza afirma que:

Não é por outro motivo que o ICMS em tela só pode surgir da execução de uma obrigação de fazer (nunca de dar), isto é, do fato de uma pessoa, física ou jurídica, prestar a título oneroso, serviços - no caso, de comunicação - a terceiros. Noutros falares, ele nasce quando, em razão de negócio jurídico firmado entre particulares, sob regime de direito

42 CARRAZZA, Roque Antonio. ICMS. 2011. p.210.

43 NETFLIX. Termos e condições de uso. Disponível em: <https://help.netflix. com/legal/termsofuse>. Acesso em 09 jun. 2018.

44 SPOTIFY. Termos e condições de uso. Disponível em: < https://www.spotify. com/br/legal/end-user-agreement/>. Acesso em 09 jun. 2018. 
privado (mas não trabalhista), serviços de comunicação forem efetivamente prestados. ${ }^{45}$

Diante da constatação do autor é possível ainda extrairmos que a incidência do imposto em questão somente ocorrerá nas hipóteses em que o serviço obrigar uma das partes a fazer determinada prestação, e não apenas entregá-la, contrariando o novo entendimento despendido pela doutrina.

Ainda que admitida por parte da doutrina a possibilidade de composição do serviço a partir de uma obrigação de "dar", ainda se faz necessária uma análise sob a expressão "comunicação", a qual, conjuntamente, compõe a materialidade do imposto em questão e que deve harmonizar com o as hipóteses de incidência.

Destacando a importância da locução, José Eduardo Soares de Melo diz que:

O conceito de "comunicação" representa o aspecto fundamental para se precisar a essência da materialidade (pertinente e integrada pela prestação de serviços). 0 fato gerador não ocorre pelo simples ato que torna possível a prestação de serviços de comunicação, sem que os sujeitos desta relação negocial (prestador e tomador - devidamente determinados) tenham uma efetiva participação. ${ }^{46}$

Ainda que codificada a informação consistente na transmissão, entre o emissor e o receptor, é necessário que eles possuam um canal comunicacional onde a mensagem passará a ser decodificada, restando assim, estabelecido o processo comunicativo. Ainda que parcialmente, não abrangendo sua totalidade, as informações necessitam de um conjunto ou uma coleção de meios

45 CARRAZZA, Roque Antonio. ICMS. 2011. p.210.

46 PAULSEN, Leandro; DE MELO, José Eduardo Soares. Impostos: federais, estaduais e municipais. Livraria do Advogado Editora, 2013. p. 243. 
capaz de elucidar o produto da comunicação ${ }^{47}$.

Roque Antonio Carrazza explica que "a comunicação [...] somente a determinará se for objeto de um contrato oneroso firmado entre as partes" ${ }^{48}$. Logo, também se afasta a cobrança do tributo, nas atividades em que os dois polos da relação se confundam. Como nos casos em que a figura do tomador e do prestador estão em apenas um sujeito, considerando assim a hipótese de um "autosserviço", não podendo atingir o tributo em questão ${ }^{49}$.

0 autor ainda complementa no mesmo sentido ao expor que:

Para que haja, pois a incidência do tributo em pauta, é mister que se faça necessário, à comunicação, o emprego de meios materiais, vale dizer, a instalação - pelo próprio prestador de serviço de comunicação ou por intermediário, que ele remunera - de toda uma infraestrutura mecânica, eletrônica e técnica (microfones, caixa de som, telefones, radiotransmissores, centrais, terminais, linhas de transmissão, satélites, etc.). E depois, é claro, que mediante a utilização destes mesmos meios materiais, duas pessoas passem a intercambiar informações. ${ }^{50}$

Portanto, a doutrina identifica que a possível incidência do ICMS-Comunicação só ocorrerá nos casos em que se qualifiquem pela onerosidade, bilateralidade, com caráter negocial e que obrigue o emissor "a fazer" a transmissão de um conteúdo por meio de um canal que garanta sua difusão.

Em verdade, partindo dessa concepção, a retribuição financeira que o consumidor entrega a empresa de que utiliza a

47 CARVALHO, Paulo de Barros. Direito tributário linguagem e método. Noeses, 2011. p.747.

48 CARRAZZA, Roque Antonio. ICMS. 2011. p.210.

49 RISTOW, Rafael Pinheiro Lucas; FARIA, Ligia Ferreira de. Streaming e a incidência (não) do ICMS: caso “TV por assinatura x Streaming”. Revista de Estudos Tributários - RET, Porto Alegre, v. 19, n. 113, p. 111-125, jan./ fev. 2017. p. 115.

50 CARRAZZA, Roque Antonio. ICMS. 2011. p.224-225. 
tecnologia streaming, poderia justificar a incidência do ICMS, na visão de diversos juristas.

Assim define Ives Gandra da Silva Martins que os:

Serviços de comunicação, para fins de ICMS, são serviços de transmissão de mensagens entre pessoas, por determinado veículo, a título oneroso.

A competência para definir quais são os serviços de telecomunicações é da União Federal, que, ao editar a Lei Geral de Telecomunicações, de forma compatível com a Constituição Federal, excluiu os serviços prestados pelos provedores. ${ }^{51}$

Além de expor a compreensão dos serviços de comunicação no Direito Tributário e esclarecer que a Lei no 9472/97 definirá quais são os serviços definidos como de telecomunicação, o autor ainda alude a não tributação pelo ICMS dos serviços prestados pelos provedores.

Ao realizar essa análise, Ives Gandra da Silva Martins ${ }^{52}$ reporta que os provedores necessitam do serviço de telecomunicação, sendo eles dependentes dessa cadeia tecnológica para que possam realizar suas atividades. De mesma forma, podemos assemelhar ao funcionamento da tecnologia streaming, uma vez que ela utiliza do mesmo serviço de telecomunicação sujeito aos provedores.

Assim, as empresas que utilizam o streaming não possuem os meios para entregar o seu conteúdo ao cliente, tendo em vista que utiliza da internet e de todo o serviço de telecomunicação para prestar seus serviços. Nesse processo, elas apenas disponibilizam seus arquivos aos assinantes sem que possuam o aparato

51 MARTINS. Ives Gandra da Silva (Coord.). Tributação na Internet: relatório do XXVI Simpósio Nacional de Direito Tributário. Boletim de Direito Municipal, São Paulo, v. 18. n. 1. jan. 2002. p. 1-5.

52 MARTINS. Ives Gandra da Silva (Coord.). Tributação na Internet: relatório do XXVI Simpósio Nacional de Direito Tributário. Boletim de Direito Municipal, São Paulo, v. 18. n. 1. jan. 2002. p.1-5. 
tecnológico para efetivamente realizar o serviço de comunicação. Logo, não há relação comunicativa entre a empresa que utiliza a tecnologia streaming e o assinante que o contrata, afastando a ideia de que o curso permeie o cedente e o cessionário.

O ex-Ministro Francisco Peçanha Martins, no acórdão que julgou a matéria dos provedores de internet salienta que "a chamada comunicação eletrônica, entre computadores, somente ocorre através das chamadas linhas telefônicas de qualquer natureza, ou seja, a cabo ou via satélite" ${ }^{53}$. A comunicação ocorrerá somente pelos serviços de telecomunicação, nos quais são definidos pelo artigo 60 da Lei Geral de Telecomunicações (LGT).

A mesma lei, no artigo 61, traz ainda a definição de serviço de valor adicionado (SVA), pelo qual se enquadrará a tecnologia streaming. Uma vez que "é a atividade que acrescenta, a um serviço de telecomunicações que lhe dá suporte e com o qual não se confunde, novas utilidades relacionadas ao acesso, armazenamento, apresentação, movimentação ou recuperação de informações" ${ }^{54}$.

Assim, com a regra trazida pelo referido artigo, exclui-se do campo de incidência do ICMS a tecnologia streaming, uma vez que por força de lei, constitui um serviço de valor adicionado. Nesse sentido, Ives Gandra Martins leciona que:

\footnotetext{
Ora, se o serviço estiver vinculado ao setor de telecomunicação, mas não for considerado serviço de telecomunicação por quem tem competência de definição fiscal, à evidência, não será serviço de comunicação de forma alguma. Ou são serviços
}

53 BRASIL. Superior Tribunal Justiça. Recurso Especial № 456.650/PR Paraná. Relatora: Ministra Eliana Calmon. Pesquisa de Jurisprudência, Acórdãos, 24 jun. 2003. Disponível em <http://stj.jus.br>. Acesso em: 06 nov. 2018.

54 BRASIL. Lei 9.472, de 16 de julho de 1997. Documento eletrônico. Disponível em: <http://www.planalto.gov.br/ccivil_03/Leis/L9472.htm>. Acesso em: 02 jun. 2018. 
de telecomunicações, por estarem vinculados a telecomunicações, ou não são meios de comunicação, por falta de pertinência com outras formas de comunicação. ${ }^{55}$

Portanto, o legislador ao editar a referida lei, tinha o intuito de separar e caracterizar juridicamente as diferenças entre os dois institutos. Além de confirmar um entendimento já consolidado pela antiga Lei $\mathrm{n}^{\circ} 9.295 / 96$, que em seu artigo $10^{\circ}$ conceituava o SVA.

Conforme o entendimento do Superior Tribunal de Justiça, no julgamento do Recurso Especial no 456.650, onde se discutia a tributação dos Provedores de Internet, ficou definido que os provedores ocupam a forma de um SVA. E nesse caso, não incidirá o ICMS-Comunicação pois "o prestador se utiliza da rede de telecomunicações que lhe dá suporte para viabilizar o acesso do usuário final à Internet, por meio de uma linha telefônica"56. Nesse entendimento, o STJ editou à súmula $n^{\circ} 334$, na qual dispõe: "O ICMS não incide no serviço dos provedores de acesso à internet."

Assim, reproduz o funcionamento da tecnologia streaming, na qual necessita do serviço de telecomunicação para conduzir o seu conteúdo ao usuário final. De modo que a comunicação apenas se perfectibiliza quando ocorre a prestação de um serviço de telecomunicação no qual dará o aparato necessário e no qual já incide o ICMS - Comunicação.

De forma contraria, o Professor Marco Aurélio Greco posiciona-se com o entendimento de que a Lei n 9472/97 não pode definir aquilo que deve ou não ser tributável, uma vez que "ela

55 MARTINS, Ives Gandra da Silva. “Tributação na Internet”. Coordenador Ives Gandra da Silva Martins, Ed. Revista dos Tribunais, São Paulo, 2001. p.48.

56 BRASIL. Supremo Tribunal Federal. Agravo de Instrumento $\mathbf{n}^{\circ}$ 643659/ MG - Minas Gerais. Relator: Ministro Marco Aurélio. Pesquisa de Jurisprudência, Acórdãos, 01 dez. 2010. Disponível em <http://stf.jus.br>. Acesso em: 02 jun. 2018. 
própria exclui do conceito de telecomunicação um serviço que, inequivocadamente, configura prestação de serviço de comunicação (provimento de capacidade em satélite)" ${ }^{57}$.

Entretanto, a ex-ministra do STJ Eliana Calmon ao analisar o texto da LGT, pondera que:

Não se olvida que, pela Internet, tem-se uma rede de comunicação entre computadores, o que resulta na prestação de serviço de transmissão, a distância, de idéias, de dados e de imagens diversas. Entretanto, segundo minha ótica, não há respaldo para que o Fisco faça nascer daí um liame jurídico, tributário, o que seria, em termos concretos, fazer incidir o ICMS sobre o tráfego telefônico, já tributado..$^{58}$

Outra analogia possível está na tecnologia de Voice Over Internet Protocol (VoIP), um sistema semelhante ao streaming que utiliza a internet para rotear conversas, convertendo sons para recepção de um usuário.

Conforme o julgamento na 7a Vara da Fazenda Pública de São Paulo do Processo nº 0010093-14.2010.8.0053, o magistrado expõe que "a tecnologia "VoIP" não possui uma estação de comunicação própria. Ela apenas se utiliza de uma rede de IP, alheia e pré-existente, para a transmissão da voz, por meio da transformação desta em dado multimídia. É, em suma, mera usuária da rede telecomunicativa, e não titular"59.

Diante do entendimento de como funciona o cenário do streaming e os meios que ele utiliza até a chegada de seus produtos

57 GRECO. Marco Aurélio. Internet e direito. 2. ed. São Paulo: Dialética, 2000. p. 223.

58 CALMON, Eliana. Informativo Jurídico da Biblioteca Ministro Oscar Saraiva. v. 15, n. 2, p. 137-265, Jul/Dez. 2003 p. 236.

59 BRASIL. Tribunal de Justiça do Estado de São Paulo. Processo 001009314.2010.26.0053. 7̣ Vara Fazenda Pública. Disponível em: <https://esaj. tjsp.jus.br>. Acesso em: 02 de jun. 2018. 
ao consumidor final, conclui-se que a hipótese de incidência do ICMS - Comunicação não se harmoniza à tecnologia pois esta não apresenta meios de suportar sozinha a transmissão do seu conteúdo. Não sendo também a titular do meio que proporciona a comunicação, mostrando-se apenas como um SVA. E que nesse sentido, não poderia cogitar a incidência devido aos serviços semelhantes já descaracterizados de incidência pelos entendimentos jurisprudenciais.

\section{DO ISSQN}

De competência municipal, o imposto sobre serviços de qualquer natureza (ISS) encontra-se positivado na constituição federal no artigo 156, inciso III. A sua própria base legal, define ainda que se trata de serviços definidos em lei completar e que não estejam abarcados pelos serviços de competência dos Estados como transporte interestadual, intermunicipal e serviços de comunicação, no caso, o ICMS.

A divisão de competência de ambos os impostos ocorreu visando a superação de um antigo imposto geral, onde deu origem ao ISSQN e ao ICMS (na época, chamado de ICM) ${ }^{60}$. Separando-os de uma unidade tributária, o legislador teve a intenção de trazer exclusividade para suas hipóteses de incidência tornando-as únicas e especificas, evitando assim que os dois impostos incidam sobre o mesmo serviço.

Nesse sentido, José Eduardo Soares de Melo e Luiz Francisco Lippo lecionam que "a exclusividade do ISS deve apartar-se das incidências de outros tributos (como é o caso do ICMS, IPI, IOF), concernentes a específicas atividades, ainda que simultâneas ou complementares à prestação de serviços" ${ }^{61}$. Entretanto, na fala

60 MARTINS, Ives Gandra da Silva. Curso de Direito Tributário. 8. ed. São Paulo: Saraiva, 2001. p. 695.

61 MELO, José Eduardo Soares de; LIPPO, Luiz Francisco. A não-cumulatividade tributária (ICMS, IPI, ISS, PIS e COFINS). 3. ed. São Paulo: Dialética, 2008. p. 81. 
dos autores, não exclui que as empresas ainda possam ser tributadas por outros impostos, caso ofereçam outro tipo de serviço, a vedação ocorre diretamente na independência da atividade.

Em julho de 2003, restou por ser editada a Lei Complementar $n^{\circ} 116$, dispondo então sobre o imposto. Conjuntamente, na referida lei complementar, foi publicada uma lista de serviços sobre os quais incide o ISS. Ainda que a Constituição tenha outorgado poderes aos Munícipios para instituir os impostos sobre os serviços de qualquer natureza, estes estão claramente subordinados ao Congresso Nacional com a edição da referida Lei complementar, restando vencida sua autonomia ${ }^{62}$.

Nesse sentido, Aires Fernandino Barreto esclarece:

\begin{abstract}
Decorrência do princípio da autonomia municipal é o de o Município editar suas normas tributárias de acordo com a competência que lhe foi outorgada pela Constituição, afastando a incursão de quaisquer outras, sejam elas federais ou estaduais. Não é demais lembrar que o Município, em razão da sua autonomia, haure diretamente da Constituição, suas competências, nela encontrando seu próprio fundamento de validade. ${ }^{63}$
\end{abstract}

Embora uma parte da doutrina entenda que houve uma supressão da autonomia municipal, a incerteza e insegurança jurídica pairavam sobre o ordenamento, uma vez que faltava um tipo de padrão sobre quais os serviços deveriam ser tributados pelo ISSQN. Autorizando assim, a deliberação dos municípios sobre o tema. Ainda que possam gerar discussões sobre o conflito de competência na incorporação da lista de serviços, o STF no teor do RE 77.183-SP de relatoria do Ministro Aliomar Baleiro, decidiu

62 PAULSEN, Leandro; DE MELO, José Eduardo Soares. Impostos: federais, estaduais e municipais. Livraria do Advogado Editora, 2013. p. 343-344.

63 BARRETO, Aires F. ISS na Constituição e na Lei. 3. ed. São Paulo: Dialética, 2009, p. 10. 
que a lista é taxativa, apesar de que se utiliza uma interpretação ampla e de raciocino analógico, conforme o RE 75.952-SP de Relatoria do Ministro Thompson Flores.

Assim, não seguindo mais os critérios municipais de definição, os serviços passaram a ser estritos a legislação complementar, respeitando então o princípio da legalidade tributária.

Em 2016, diante do crescente número de atividades advindas com os avanços tecnológicos e principalmente com a expansão da tecnologia streaming no mercado, surgiu a necessidade de tributar os novos serviços delas decorrentes. Logo, diante do entendimento de Maria Juliana de Almeida Fonseca, se faz necessário que:

Caso surja um novo serviço de qualquer natureza que esteja fora das restrições implícitas impostas na Constituição e potencialmente passível de tributação pelos Municípios, faz-se necessária a inclusão desse serviço na lista de serviço para que esse seja tributado pelos Municípios. ${ }^{64}$

O legislador editou então a $\mathrm{LC} \mathrm{n}^{\circ}$ 157/16. A mencionada lei complementar, alterou a lista de serviços provinda da LC 116/03, integrando em um de seus subitens uma classificação atinente aos serviços de streaming.

O subitem 1.09, incorporado pela nova lei, refere-se a serviços de disponibilização, sem cessão definitiva, de conteúdos de áudio, vídeo, imagem e texto por meio da internet, respeitada a imunidade de livros, jornais e periódicos, com a exceção da distribuição de conteúdos pelas prestadoras de serviços de acesso condicionado, na qual estão sujeitas ao ICMS. A partir do texto legal, restou clara a intenção do legislador em enquadrar a tecnologia streaming na incidência do ISSQN.

64 FONSECA, Maria Juliana de Almeida. Conflitos de competência tributária - ICMS e ISSQN. Os novos conceitos de mercadoria e serviço. Belo Horizonte: Del Rey, 2005. p. 68. 
Ainda que a lei traga a exceção de que os Serviços de Acesso Condicionado estarão sujeitos ao ICMS, esses não se confundem com os Serviços de Valor Adicionado. Uma vez que o SVA não constitui um serviço de telecomunicação, sendo apenas um usuário deste serviço, porquanto, constitui uma complementação das atividades prestadas pelas empresas de telecomunicação.

Ainda que atualmente algumas companhias já tenham seus serviços fundidos, tanto na prestação de serviço de telecomunicação, como nos de acesso e de valor adicionado, não se pode confundir na aplicação da incidência própria de cada instituto. Posto que o STJ, no julgamento do Recurso Especial 456.650/PR, já deliberou que a incidência de ICMS só ocorrerá onde exista a presença de rede de telecomunicação.

De início, a fim de analisar a incidência do ISSQN na tecnologia streaming, precisamos observar o núcleo de seu critério material, no qual percorre a interpretação do signo "serviço". Apesar de já conceituado no presente trabalho, o serviço, frente aos critérios tecnológicos, precisa observar o princípio da capacidade contributiva. É nesse sentido que Andrei Pitten Velloso afirma:

Repudiadas as finalidades arrecadatórias e econômicas como validas a embasar a exegese teleológica dos enunciados tributários, torna-se evidente que o desenvolvimento da interpretação teleológico-objetiva deve estar embasado nos princípios jurídicos-constitucionais e constitucional-tributários, que, permeando todo o subsistema constitucional-tributário, conferem-lhe racionalidade e nortes axiológicos. Desse modo, princípios como o da capacidade contributiva e da isonomia hão de ser considerados pelo interprete para, dentro das variantes de significado deixadas em aberto pelo sentido literal e pelo contexto de significado, proceder à definição do conteúdo semântico dos signos linguísticos empregados pelo constituinte para a outorga de competências impositivas. ${ }^{65}$

65 VELLOSO, Andrei Pitten. Conceitos e competências tributarias. São Paulo, Dialética, 2005, p. 204. 
O entendimento do autor contribui ainda com os escritos de Gustavo Masina, onde ele afirma que "o princípio da capacidade contributiva impõe que apenas os serviços que apresentem conteúdo econômico possam dar ensejo à incidência do ISSQN - excluídos, assim, os gratuitos" ${ }^{\prime 66}$. Desse modo, se faz necessário entender que o conteúdo econômico da prestação de serviço não está vinculado ao contrato de serviço, mas sim, com o princípio da capacidade contributiva absoluta, onde então surge a "aptidão genérica para pagar tributos" ${ }^{67}$.

Ainda sobre o critério material do ISSQN, nas palavras de Melo:

O cerne da materialidade da hipótese tributária do imposto em comento não se circunscreve a "serviço", mas a uma "prestação de serviço", compreendendo um negócio (jurídico) pertinente a uma obrigação de "fazer", de conformidade com os postulados e diretrizes do direito privado. ${ }^{68}$

Portanto, a construção desta linha de pensamento, vem de uma interpretação dos artigos 109 e 110 do CTN, nos quais cercam a definição jurídica com base no direito privado. Levando então a restringir a incidência do imposto apenas nas obrigações de "fazer". Por outro lado, Andrei Pitten Velloso acredita que interpretação do problema em definir o conceito de serviço, deve ser solucionado com base na Constituição, afastando assim o artigo 110 do CTN. Uma vez que o texto constitucional não utilizou o conceito de direito privado para defini-lo como tal ${ }^{69}$.

66 MASINA, Gustavo. ISSQN: regra de competência e conflitos tributários. Porto Alegre, Livraria do Advogado Editora, 2009. p. 78.

67 GONZÁLES, Eusebio; LEJEUNE, Ernesto. Derecho Tributario. Salamanca: Plaza Universitaria Ediciones, 1997. v. I. p.161.

${ }_{68}$ DE MELO, José Eduardo Soares. Aspectos teóricos e práticos do ISS. 2a Ed. São Paulo: Dialética, 2001. p. 31.

69 VELLOSO, Andrei Pitten. Conceitos e Competências Tributárias. São Paulo: Dialética, 2005, p. 99- 100. 
De maneira diversa, Humberto Ávila explica que:

\begin{abstract}
Essa exclusividade conceitual permite saber tanto o que o termo constitucional pode significar quanto o que ele não pode significar. Como, por exemplo, o poder para tributar as vendas de bens e, portanto, as obrigações de dar, foi atribuído aos Estados pela competência para instituir o Imposto sobre a Circulação de Mercadorias, a palavra "serviços", na regra de competência para tributar a prestação de serviços, só pode ser conceituada como uma obrigação de fazer. ${ }^{70}$
\end{abstract}

Ao adotarmos essa corrente restrita em que confina o verbo nuclear da hipótese material do ISSQN, apenas as obrigações de "fazer", podemos afirmar que a edição do subitem 1.09, não estará em consonância com as regras definidas pela doutrina. Uma vez que a mera disponibilização de conteúdo através da tecnologia streaming, consistirá em uma exclusiva obrigação de dar. Assim, não sendo mais considerada uma prestação de serviço, restaria a configuração da tecnologia de streaming como mera locação de bem móvel.

Nesse sentido, Orosimbo Nonato explica que a obrigação de dar "tem por objeto a entrega de uma coisa ao credor para que este adquira sobre a mesma um direito"71. Fundado na conceituação do autor, é possível observar, de maneira prática, que o sujeito ativo entrega o conteúdo, "seja para lhe transferir a propriedade, seja para lhe ceder a posse, seja para restituí-la"72.

70 Ávila, Humberto. Imposto sobre a prestação de serviços de qualquer natureza - ISS. Norma constitucionais aplicáveis. Precedentes do Supremo Tribunal Federal. Hipótese de Incidência. Base de cálculo e local da prestação. Leasing financeiro: análise de incidência. Revista Dialética de Direito Tributário n. 122. 2005. p. 122/123.

71 NONATO, Orosimbo. Curso de obrigações. Rio de Janeiro. Forense. 1959. v. 1, p. 287.

72 GOMES, Orlando. Obrigações. Forense. 17 ed. Rio de Janeiro. 2007. p.47. 
Os conteúdos apresentados pelas plataformas que utilizam a tecnologia streaming, funcionam como se estivessem expostos em prateleiras, de forma que o sujeito passivo (usuário) apossar-se-á dos mesmos, gerando um novo direito. Assim funciona a empresa Netflix, a grande sucessora das antigas locadoras de filmes, que nada obstante, utilizavam este mesmo método por meios físicos e não digitais.

É comum que advenham dúvidas sobre as obrigações de dar e de fazer, principalmente no âmbito digital, uma vez que "dar ou entregar alguma coisa é também fazer alguma coisa"73. Entretanto, Carlos Roberto Gonçalves conceitua que:

A obrigação de fazer (obligatio faciendi) abrange o serviço humano em geral, material ou imaterial, a realização de obras e artefatos ou a prestação de fatos que tenham utilidade para o credor. A prestação consiste, assim, em atos ou serviços a serem executados pelo devedor. Pode-se afirmar, em síntese, que qualquer forma de atividade humana lícita, possível e vantajosa ao credor pode constituir objeto da obrigação. ${ }^{74}$

Com o intuito de esclarecer a diferença entre as duas obrigações, Washington Barros Monteiro explica:

O substractum da diferenciação entre a obrigação de dar e fazer está em verificar se o dar ou o entregar é ou não conseqüência do fazer. Assim, se o devedor tem de dar ou de entregar alguma coisa, não tendo, porém, de fazê-la previamente, a obrigação é de dar; todavia, se, primeiramente, tem ele de confeccionar a coisa para depois entregá-la, se tem ele de realizar algum ato, do qual ser mero corolário o de dar, tecnicamente a obrigação é de fazer. ${ }^{75}$

73 GONÇALVES, Carlos Roberto. Direito Civil Brasileiro, Teoria Geral das Obrigações. Vol. II, São Paulo: Saraiva, 2013. p. 85.

74 GONÇALVES, Carlos Roberto. Direito Civil Brasileiro, Teoria Geral das Obrigações. Vol. II, São Paulo: Saraiva, 2013. p. 84.

75 MONTEIRO, Washington Barros. Curso de Direito Civil: Direito das Obrigações. Editora Saraiva, 2017. p. 87. 
Portanto, é possível afirmar que o serviço prestado através da utilização da tecnologia de streaming, constitui uma obrigação de "dar", uma vez que a disponibilização de seu conteúdo já se encontra pronto e não necessita prévia confecção.

Dessa forma, não caracterizando uma obrigação de "fazer", uma vez que não coaduna com seu sistema de funcionamento, restaria um enquadramento na forma de locação de bens móveis. Ainda que dimensionado nesta forma, pois compõe uma obrigação de "dar", o STF editou a Súmula Vinculante 31 onde afastou esta possibilidade, através do seguinte apontamento: "É inconstitucional a incidência do imposto sobre serviços de qualquer natureza - ISS sobre operações de locação de bens móveis".

Nesse sentido, precedia, anteriormente a edição da Súmula, o entendimento do Relator Ministro Marco Aurélio, no qual firmava sua posição na Suprema Corte através do RE 116.121, conforme ementa, ipsis litteris:

TRIBUTO. FIGURINO CONSTITUCIONAL. A supremacia da Carta Federal é conducente a glosar-se a cobrança de tributo discrepante daqueles nela previstos. Imposto Sobre Serviços. Contrato de locação. A terminologia constitucional do Imposto Sobre Serviços revela o objeto da tributação. Conflita com a Lei Maior dispositivo que imponha o tributo considerado contrato de locação de bem móvel. Em Direito, os institutos, as expressões e os vocábulos têm sentido próprio, descabendo confundir a locação de serviços com a de móveis, práticas diversas regidas pelo Código Civil/1916, cujas definições são de observância inafastável — art. 110 do CTN/1966. ${ }^{76}$

$76 \quad$ BRASIL. Supremo Tribunal Federal. Recurso Extraordinário no 116.121 Relator: Ministro Marco Aurélio. Pesquisa de Jurisprudência, Acórdãos, 11 out. 2000. Disponível em:<http://www.stf.jus.br> Acesso em: 22 out. 2018. 
Diante da nomenclatura atribuída ao tributo, os serviços de qualquer natureza não se inserem em uma forma restrita e limitada, uma vez que precisam acompanhar os avanços tecnológicos advindos com a modernização. Assim, Nelson Rosenvald explica que nos dias de hoje "a obrigação deve ser vista como uma relação complexa, formada por um conjunto de direitos, obrigações e situações jurídicas, compreendendo uma série de deveres de prestação, direitos formativos e outras situações jurídicas"77.

Para isso, cabe uma análise da concepção atribuída pela visão moderna do conceito de serviço nas relações obrigacionais, a fim de que não fiquemos presos a uma análise clássica do conceito.

Um dos primeiros precedentes a admitir uma interpretação mais extensa sob a visão de como a Constituição enxerga o termo "serviço", está no julgado de ex-Ministro Eros Grau, que na relatoria do Recurso Extraordinário 592.905, entendeu por permitir a incidência de ISSQN nas operações de leasing. Na ocasião, ele defende que "serviço" não está confinado a definição da lei complementar, ela apenas o clarifica para cumprir o propósito do inciso III do artigo 156 da Constituição Federal ${ }^{78}$.

A partir de uma visão moderna, o ex-Ministro, defende em seu voto que:

Em síntese, há serviços, para os efeitos do inciso III do artigo 156 da Constituição, que por serem de qualquer natureza, não consubstanciam típicas obrigações de fazer. Raciocínio adverso a este conduziria à afirmação de que haveria serviço apenas nas prestações de fazer, nos termos do que define o direito privado. Nota-se, contudo, que afirmação

77 ROSEnVALD, Nelson. Dignidade humana e boa-fé no Código Civil. Editora Saraiva, 2005. p.204.

78 BRASIL. Supremo Tribunal Federal. Recurso Extraordinário no 592.905. Relator: Ministro Eros Grau. Pesquisa de Jurisprudência, Acórdãos, 02 dez. 2009. Disponível em:< http://www.stf.jus.br> Acesso em: 02 jun. 2018. 
como tal faz tábula rasa da expressão "de qualquer natureza”, afirmada do texto da Constituição. Não me excedo em lembrar que toda atividade de dar consubstancia também um fazer e há inúmeras atividades de fazer que envolvem um dar. ${ }^{79}$

A vista disso, os novos serviços introduzidos no mercado, diante das inovações científicas, não se confinam apenas em obrigações de "fazer" e sim, tendo em vista todos seus métodos de propagação de conteúdo, em obrigações de "dar". O Ministro Luiz Fux, sustenta a expansão das hipóteses de incidência do ISSQN, a partir da análise do conceito de prestação de serviço, ao demonstrar a partir de seu voto, no Recurso Extraordinário $\mathrm{n}^{\circ}$ 651.703, que o "oferecimento de uma utilidade para outrem, a partir de um conjunto de atividades materiais ou imateriais, prestadas com habitualidade e intuito de lucro, podendo estar conjugada ou não com a entrega de bens ao tomador" ${ }^{80}$.

Logo, estaria correta a previsão legal do subitem 1.09, uma vez que as empresas que utilizam a tecnologia streaming, permitem o acesso dos usuários sobre filmes, músicas, séries e outras mídias digitais, através de uma vinculo obrigacional de "dar". Onde também buscam o lucro por meio da prática de disponibilização aos seus assinantes de utilidades imateriais. Segundo o próprio Ministro, o Direito Civil não tem competência exclusiva para definir o que se entende por "prestar serviços", uma vez que a Constituição buscou englobar todos os serviços tributáveis, deixando de forma residual a incidência do imposto municipal em questão, os serviços de qualquer natureza, não tributáveis

79 BRASIL. Supremo Tribunal Federal. Recurso Extraordinário no 547.245. Relator: Ministro Eros Grau. Pesquisa de Jurisprudência, Acórdãos, 02 dez. 2009. Disponível em:< http://www.stf.jus.br> Acesso em: 02 jun. 2018.

80 BRASIL. Supremo Tribunal Federal. Recurso Extraordinário no 651.703. Relator: Ministro Luiz Fux. Pesquisa de Jurisprudência, Acórdãos, 29 set. 2016. Disponível em:<http://www.stf.jus.br> Acesso em: 02 jun. 2018. 
pelos outros impostos ${ }^{81}$.

Isto posto, o legislador constitucional adotou o conceito econômico de serviço, uma vez que aplicou o caráter residual ao imposto, definindo pela expressão "de qualquer natureza". 0 vocábulo resulta em compreensão facilitada do instituto, uma vez que todo o remanescente, busca abranger inúmeras formas de atividade econômica ${ }^{82}$.

Assim, entendeu o legislador que a tecnologia streaming se encaixa na visão moderna de serviço e por isso atende a regra de incidência do ISSQN. A questão é que podemos observar uma ampliação, por parte da doutrina, na forma de interpretação dos itens previstos na Lista de Serviços vinculada a Lei $n^{\circ} 116$. Uma vez que a expansão tecnológica e a demanda social por novas práticas, criam obrigações de natureza hibrida, bem como novas formas de prestar seus serviços.

\section{CONSIDERAÇÕES FINAIS}

Os fatos sociais e jurídicos, condicionantes do cotidiano, nas relações de Estado e sociedade, que motivam a atuação do aplicador e interpretador da norma, necessitam análises profundas acerca de suas concepções. A partir do dinamismo do mercado na utilização de novas tecnologias, principalmente no setor digital, se mostram um desafio para as autoridades tributárias no tocante a aplicação da legislação vigente.

Este artigo não pretende apresentar uma solução concreta para a forma de tributar a tecnologia streaming. Assim, propõe-se

81 BRASIL. Supremo Tribunal Federal. Recurso Extraordinário no 651.703. Relator: Ministro Luiz Fux. Pesquisa de Jurisprudência, Acórdãos, 29 set. 2016. Disponível em:<http://www.stf.jus.br> Acesso em: 02 jun. 2018.

82 MACEDO, Alberto. ISS - O Conceito Econômico de Serviços Já Foi Juridicizado Há Tempos Também pelo Direito Privado. In: XII Congresso Nacional de Estudos Tributários - Direito Tributário e os Novos Horizontes do Processo. MACEDO, Alberto [et all]. - São Paulo: Editora Noeses, 2015, p. 71/79. 
a buscar uma visão ampla com base na doutrina e na jurisprudência para que a partir das hipóteses levantadas, possamos analisar o enquadramento em uma das formas de tributação presentes no ordenamento jurídico. Nessa perspectiva, alguns conceitos basilares do direito tributário foram confrontados com a ascendente tecnologia de streaming, uma vez que essa, revelou-se como um grande e potencial de serviço passível à incidência tributária.

Em primeira análise, percebemos que a concepção moderna do termo "serviço", a partir dos votos ministrais no STF, abarcou os novos fatos decorrentes da interação de usuários com a internet. Uma vez que o antigo entendimento doutrinário visava enquadrar apenas as formas de serviço que constituíssem obrigações de "fazer". A nova visão traz para o ordenamento o aditamento dessa compreensão, a partir de que o processo de cumprimento de algumas atividades, principalmente aquelas que utilizam ou são meios tecnológicos, podem se inserir como uma obrigação de "dar". Analisou-se que o serviço de streaming não está harmonizado com os critérios materiais da hipótese de incidência do ICMS - Comunicação. Pois, ainda que este possua um caráter negocial, oneroso e bilateral na prestação, o prestador não possui os aparatos tecnológicos para sustentar a tecnologia. Uma vez que o serviço de telecomunicação precede todo o funcionamento e assume o papel de intermediário na relação, visto que possui os aparatos tecnológicos necessários para que a transmissão via stream seja entregue ao receptor.

Logo, ao constatar que a tecnologia streaming não possui capacidade para completar a comunicação entre as partes obrigadas, necessitando de um intercessor, não estará sujeita ao imposto estadual, uma vez que consistirá em um Serviço de Valor Adicionado. Esta análise foi feita a partir da analogia ao entendimento apontado pela Suprema Corte aos provedores de internet, aos quais também carecem do serviço de telecomunicação para seu funcionamento. 
Averiguou-se que o critério material da regra-matriz de incidência do ISSQN, a partir do antigo entendimento doutrinário, é incapaz de enquadrar a hipótese de tributação do serviço de streaming pelo imposto municipal. Entretanto, assentado no ponto de vista moderno na concepção do vocábulo "serviço", a nova tecnologia estará de acordo com a legislação vigente. Sem que haja qualquer inconstitucionalidade na edição da Lei Complementar que a incluiu na lista de serviços tributáveis pelo imposto.

Ainda que o entendimento sobre o conceito de "serviço" tenha sido alongado, as novas tecnologias ainda se inserem em uma lacuna legislativa, necessitando de normas ou formas de tributação especificas que comportem o seu segmento. Para que então, os institutos já assentados na doutrina não sejam modificados e estendidos a partir de critérios econômicos e de que capacidade contributiva.

A alta carga tributária no Brasil é sempre um assunto em voga por afetar diretamente o consumidor final das relações. Os serviços de telecomunicação, bem como aqueles vinculados a ele, são setores de altas taxas e elevados custos. É necessário que o legislador defina com rigor e abarque as novas formas tecnológicas incorporadas no mercado com a legislação vigente. Haja vista que, uma legislação anacrônica oferece maiores riscos de uma aplicação errônea na forma de tributar, bem como, pode levar a uma bitributação.

\section{REFERÊNCIAS}

ATALIBA, Geraldo. Hipóteses de Incidência Tributária. São Paulo: Malheiros, 2009.

ATALIBA, Geraldo; BARRETO, Aires F. ISS-Locação e leasing. Revista de Direito Tributário, v. 14, n. 51,1990.

ÁVILA, Humberto. Imposto sobre a prestação de serviços de qualquer natureza-ISS. Norma constitucionais aplicáveis. Precedentes do Supremo Tribunal Federal. Hipótese de Incidência. Base de cálcu- 
lo e local da prestação. Leasing financeiro: análise de incidência. Revista Dialética de Direito Tributário n. 122. 2005.

. Teoria dos Princípios. 9a ed. São Paulo: Editora Malheiros, 2009. BARRETO, Aires F. ISS na Constituição e na Lei. 3. ed. São Paulo: Dialética, 2009.

ISS-Atividade-meio e serviço-fim. Revista Dialética de Direito Tributário, v. 5, p. 72-97, 1996.

BARROSO, Luís Roberto. A nova interpretação constitucional: ponderação, direitos fundamentais e relações privadas. $3^{a}$ ed. - Rio de Janeiro: Renovar, 2008.

BIFANO, Elidie Palma. 0 negócio eletrônico e o sistema tributário brasileiro. São Paulo: Quartier Latin, 2004.

BRASIL. CONSTITUIÇÃO DE 1988. Documento eletrônico. Disponível em: <http://www.planalto.gov.br/ccivil_03/constituicao/constituicaocompilado.htm>. Acesso em: 02 de jun. de 2018.

BRASIL. LEI 12.965, de 23 de abril de 2014. Documento eletrônico. DISPONÍVEL EM:<HTTP: //WWW.PLANALTO.GOV.BR/CCIVIL_03/_ ATO2011-2014/2014/LEI/L12965.HTM >. ACESSO EM: 21 OUT. 2018.

BRASIL. Lei 5.172, de 25 de outubro de 1966. Documento eletrônico. Disponível em: <http://www.planalto.gov.br/ccivil_03/Leis/L5172.htm>. Acesso em: 02 jun. 2018.

BRASIL. LEI 9.472, DE 16 DE JULHO DE 1997. Documento eletrônico. DISPONÍVEL EM:<HTTP://WWW.PLANALTO.GOV.BR/CCIVIL_03/LEIS/ L9472.HTM>. ACESSO EM: 02 JUN. 2018.

BRASIL. Lei Complementar $n^{\circ} 116$, de 31 de julho de 2003. Documento eletrônico. Disponível em: <http://www.planalto.gov.br/ccivil_03/ Leis/LCP/Lcp116.htm>. Acesso em: 02 jun. 2018.

BRASIL. Lei complementar $n^{\circ} 157$, de 29 de dezembro de 2016. Documento eletrônico. Disponível em:<http://www.planalto.gov.br/ ccivil_03/Leis/lcp/Lcp157.htm>. Acesso em: 02 jun. 2018.

BRASIL. Lei Complementar ${ }^{\circ}$ 87, de 13 de setembro de 1996. Documento eletrônico. Disponível em:<http://www.planalto.gov.br/ccivil_03/ Leis/lcp/Lcp87.htm>. Acesso em: 02 jun. 2018.

BRASIL. Superior Tribunal de Justiça. Recurso Especial $\mathbf{n}^{\circ} 1559264$ RJ

- Rio de Janeiro. Relator: Ministro Ricardo Villas Bôas Cueva, Pesquisa 
de Jurisprudência, Acórdãos, 08 fev. 2017. Disponível em: <http://www. stj.jus.br>. Acesso em: 02 jun. 2018.

BRASIL. Superior Tribunal Justiça. Recurso Especial № 456.650/PR Paraná. Relatora: Ministra Eliana Calmon. Pesquisa de Jurisprudência, Acórdãos, 24 jun. 2003. Disponível em <http://stj.jus.br>. Acesso em: 06 nov. 2018.

BRASIL. Supremo Tribunal Federal. Agravo de Instrumento ${ }^{\circ}$ 643659/ MG - Minas Gerais. Relator: Ministro Marco Aurélio. Pesquisa de Jurisprudência, Acórdãos, $01 \mathrm{dez}$. 2010. Disponível em <http://stf.jus.br>. Acesso em: 02 jun. 2018.

BRASIL. Supremo Tribunal Federal. Recurso Extraordinário no 116.121 Relator: Ministro Marco Aurélio. Pesquisa de Jurisprudência, Acórdãos, 11 out. 2000. Disponível em:<http://www.stf.jus.br> Acesso em: 22 out. 2018.

BRASIL. Supremo Tribunal Federal. Recurso Extraordinário no 166.772. Relator: Ministro Marco Aurélio. Pesquisa de Jurisprudência, Acórdãos, 12 mai. 1994. Disponível em:<http://redir.stf.jus.br/ paginadorpub/paginador.jsp?docTP=AC\&docID=216095> Acesso em: 10 dez. 2018.

BRASIL. Supremo Tribunal Federal. Recurso Extraordinário no 547.245. Relator: Ministro Eros Grau. Pesquisa de Jurisprudência, Acórdãos, 02 dez. 2009. Disponível em: <http://redir.stf.jus.br/paginadorpub/paginador.jsp?docTP=AC\&docID=609062> Acesso em: 02 jun. 2018.

BRASIL. Supremo Tribunal Federal. Recurso Extraordinário no 547.245. Relator: Ministro Eros Grau. Pesquisa de Jurisprudência, Acórdãos, 02 dez. 2009. Disponível em: <http://redir.stf.jus.br/paginadorpub/paginador.jsp?docTP=AC\&docID=609062> Acesso em: 02 jun. 2018.

BRASIL. Supremo Tribunal Federal. Recurso Extraordinário no 592.905. Relator: Ministro Eros Grau. Pesquisa de Jurisprudência, Acórdãos, 02 dez. 2009. Disponível em:< http://www.stf.jus.br $>$ Acesso em: 02 jun. 2018.

BRASIL. Supremo Tribunal Federal. Recurso Extraordinário no 651.703. Relator: Ministro Luiz Fux. Pesquisa de Jurisprudência, Acórdãos, 29 set. 2016. Disponível em:<http://www.stf.jus.br> Acesso em: 02 jun. 2018.

BRASIL. Tribunal de Justiça do Estado de São Paulo. Processo 001009314.2010.26.0053. 7a Vara Fazenda Pública. Disponível em: <https:// esaj.tjsp.jus.br>. Acesso em: 02 de jun. 2018. 
BRITO, Samuel Henrique Bucke. Análise de negócios na oferta do serviço de TV digital via IP (IPTV) no Brasil. Dissertação (Mestrado em Engenharia Elétrica) - Pontifícia Universidade Católica de Campinas, Campinas. 2008.

CALMON, Eliana. Informativo Jurídico da Biblioteca Ministro Oscar Saraiva. v. 15, n. 2, p. 137-265, Jul/Dez. 2003.

CARRAZZA, Roque Antonio. ICMS. 2011.

ICMS. 9. ed. São Paulo: Malheiros, 2005.

CARVALHO, Paulo de Barros. Curso de direito tributário. 17. ed. São Paulo: Saraiva, 2005.

Curso de Direito Tributário. São Paulo: Saraiva, 2010.

Direito tributário linguagem e método. Noeses, 2011.

CASSONE, Vitório. Direito Tributário. 19. ed. São Paulo: Atlas, 2008.

COÊLHO, Sacha Calmon Navarro. Curso de Direito Tributário Brasileiro. 6.ed. Rio de Janeiro: Forense, 2001.

CORAZZA, Edison Aurélio. ICMS sobre prestações de serviços de comunicação. São Paulo: Quartier Latin, 2006.

DE MELO, José Eduardo Soares. Aspectos teóricos e práticos do ISS. 2a Ed. São Paulo: Dialética, 2001.

FERREIRA SOBRINHO, José Wilson. Direito tributário: temas pontuais. Rio de Janeiro: Forense, 2001.

FONSECA, Maria Juliana de Almeida. Conflitos de competência tributária - ICMS e ISSQN. Os novos conceitos de mercadoria e serviço. Belo Horizonte: Del Rey, 2005. Disponível em: <https://books.google. com.br/>. Acesso em: 19 out. 2018.

FOROUZAN, Behrouz A. Protocolo TCP/IP [recurso eletrônico]. Tradução: João Eduardo Nóbrega Tortello. 3. ed. Porto Alegre: AMGII, 2010. Disponível em: <https://books.google.com.br >. Acesso em: 20 out. 2018.

GOMES, Orlando. Obrigações. Forense. 17 ed. Rio de Janeiro. 2007.

GONÇALVES, Carlos Roberto. Direito Civil Brasileiro, Teoria Geral das Obrigações. Vol. II, São Paulo: Saraiva, 2013.

GONZÁLES, Eusebio; LEJEUNE, Ernesto. Derecho Tributario. Salamanca: Plaza Universitaria Ediciones. v. I. 1997. 
GRECO, Marco Aurélio; ZONARI, Anna Paula. ICMS - Materialidade e princípios constitucionais. In: MARTINS, Ives Granda da Silva (Coord.). Curso de direito tributário. 2. Ed. Belém: CEJUP, v. 2, 1993.

GRECO. Marco Aurélio. Internet e direito. 2. ed. São Paulo: Dialética, 2000.

HOUAISS, Antônio; VILLAR, Mauro; DE MELLO FRANCO, Francisco Manoel. Dicionário Houaiss da língua portuguesa. 2001.

KELSEN, Hans. Teoria pura do direito. 6. ed. Tradução de João Baptista Machado. São Paulo: Martins Fontes, 1998.

MACEDO, Alberto. ISS - O Conceito Econômico de Serviços Já Foi Juridicizado Há Tempos Também pelo Direito Privado. In: XII Congresso Nacional de Estudos Tributários - Direito Tributário e os Novos Horizontes do Processo. MACEDO, Alberto [et all]. - São Paulo: Editora Noeses, 2015.

MACHADO, Hugo de Brito. Curso de direito tributário. 28. ed. Malheiros, 2007.

MARTINS, Ives Gandra da Silva. "Tributação na Internet”. Coordenador Ives Gandra da Silva Martins, Ed. Revista dos Tribunais, São Paulo, 2001.

MARTINS, Ives Gandra da Silva. Curso de Direito Tributário. 8. ed. São Paulo: Saraiva, 2001.

(Coord.). Tributação na Internet: relatório do XXVI Simpósio

Nacional de Direito Tributário. Boletim de Direito Municipal. São Paulo, v. 18. n. 1, p. l-S. jan. 2002.

MASINA, Gustavo. ISSQN: regra de competência e conflitos tributários. Porto Alegre, Livraria do Advogado Editora, 2009.

MELO, José Eduardo Soares de; LIPPO, Luiz Francisco. A não-cumulatividade tributária (ICMS, IPI, ISS, PIS e COFINS). 3. ed. São Paulo: Dialética, 2008.

MONTEIRO, Washington Barros. Curso de Direito Civil: Direito das Obrigações. Editora Saraiva, 2017.

MOREIRA, André Mendes. A tributação dos serviços de comunicação. Dialética, 2006.

NONATO, Orosimbo. Curso de obrigações. Rio de Janeiro. Forense, 1959. 
PAULSEN, Leandro; DE MELO, José Eduardo Soares. Impostos: federais, estaduais e municipais. Livraria do Advogado Editora, 2013.

Portal G1. Globo. Streaming de música torna-se principal fonte de renda do setor pela $1^{\mathbf{a}} \mathbf{v e z}$, diz relatório. Brasil, 2018. Disponível em $<$ https://g1.globo.com/pop-arte/musica/noticia/streaming-de-musica-torna-se-principal-fonte-de-renda-do-setor-pela-1-vez-diz-relatorio. ghtml> Acesso em 02 jun. 2018.

PORTAL GOOGLE. Google tradutor. Disponível em <https://translate. google.com.br >. Acesso em 02 de jun. de 2018.

REALE, Miguel. Lições preliminares de direito. São Paulo: Saraiva, 2002.

RISTOW, Rafael Pinheiro Lucas; FARIA, Ligia Ferreira de. Streaming e a incidência (não) do ICMS: caso "TV por assinatura x Streaming". Revista de Estudos Tributários - RET, Porto Alegre, v. 19, n. 113, p. 111-125, jan./fev. 2017.

SAWAYA, Márcia Regina. Dicionário de informática \& Internet. NBL Editora, 1999.

TURNER, David; MUÑOZ, Jesus. Para os filhos dos filhos dos nossos filhos: Uma visão da sociedade Internet. Plexus. São Paulo, v. 1, 2002. VELLOSO, Andrei Pitten. Conceitos e competências tributárias. São Paulo, Dialética, 2005. 